\title{
Who Owns These Tissues? General Principles on the Use of Material Submitted to Pathology Departments for Healthcare, Education and Research Purposes
}

\author{
Bu Dokular Kime Ait? Patoloji Bölümlerine Gönderilen Dokuların \\ Sağlık Hizmeti, Eğitimi ve Araştırmaları İçin Kullanımında Genel İlkeler
}

\author{
Sümeyye EKMEKÇi' ${ }^{1}$, Osman Arıkan NACAR ${ }^{2}$, Tarık TiHAN ${ }^{3}$ \\ Department of Pathology, ${ }^{2}$ Dokuz Eylül University, Faculty of Medicine, IZMIR, TURKEY, ${ }^{3}$ University of California San FrancisCo, SAN FRANCISCO, USA, \\ ${ }^{2}$ Department of Neurosurgery, Ankara Numune Education and Research Hospital, ANKARA, TURKEY
}

\begin{abstract}
The study of human tissues procured through invasive procedures for diagnostic and treatment purposes constitutes one of the most important functions of pathology departments worldwide. The final diagnosis, determination of appropriate therapy and detailed insight on many diseases are possible only through the analysis of these tissues with the use of modern analytical techniques. While these statements present no controversy, the laws and regulations on how to use these tissues for diagnostic, educational and research purposes are woefully insufficient and cause significant debate. In addition to the lack of principles that define the possession and use of these tissues, there are a number of prejudices in our country that are not consistent with the scientific and medical facts. This study aims to frame the problems arising in this matter and provides a review of the rules, experience and legislation in various countries with a discussion of some examples. We aim to provide ideas on the general fundamental principles that should be incorporated in future legislation in our country. We also hope that our study initiates a healthy discussion of this critical topic.
\end{abstract}

Key Words: Pathology, Ownership, Review, Informed consent, Ethics committee

\begin{abstract}
ÖZ
Dünyada ve ülkemizde cerrahi girişimlerden sonra hastalardan gerek tanısal gerekse sağaltımsal nedenlerle çıkarılan dokuların incelenmesi patoloji bölümünün en önemli görevlerinden birini oluşturur. Birçok hastalığın kesin tanısının belirlenmesi, hastalığa etkili tedavinin saptanması ve hastalıklar hakkında daha derin ve ayrıntılı bilgi edinilmesi ancak bu dokuların modern yöntemlerle incelenmesi sonucu gerçekleşir. Bu konu hiç tartışma götürmezken, alınan dokuların gerek sağlık hizmeti, gerek tıp eğitimi gerekse araştırma konusunda nasıl kullanılması gerektiğini belirleyen yasalar yeterli değildir. Dokuların mülkiyet ve kullanım hakları konusunda açık olması gereken ilkeler olmadığı gibi, özellikle ülkemizde bu konuda bilimsel ve tıbbi gerçeklere dayanmayan önyargılar bulunmaktadır. Çalışmamızda bu konuda var olan sorunların tanımlanması, uluslararası bağlamda var olan kural, deneyim ve örneklerin tartışılması ve gelecekte hazırlanması düşünülen yasalarda olması gereken temel prensiplerin ortaya konulması amaçlanmıştır. Çalışmamız ile bu kritik konuda ülkemizde bir diyaloğun başlayacağını ümit ediyoruz.
\end{abstract}

Anahtar Sözcükler: Patoloji, Mülkiyet hakları, Derleme, Aydınlatılmış onam, Etik kurulları

\section{THE USE OF TISSUES IN PATHOLOGY WORKFLOW}

The study of human tissues procured through invasive procedures for diagnostic and treatment purposes constitutes one of the most important functions of pathology departments worldwide. These tissues are processed using complex techniques in order to provide the necessary products that will allow diagnosis, prognostication and further understanding of the disease process through education and research. Different products emerge during their processing to allow them to be analyzed pathologically and their subsequent archiving and preserving. It is possible

(Turk Patoloji Derg 2012, 28:189-194)

Received : 02.05.2012 Accepted : 04.06.2012 to categorize these products in three different groups based on the material used and the effort spent: 1 - fresh or frozen tissues that have not undergone substantial processing, 2tissues that are processed and made suitable for diagnosis and long-term preservation (paraffin blocks, fixed tissues), 3- tissues that are made suitable for diagnostic studies using special stains and chemical analyses through complex processing (slides, immunohistochemistry and molecular analyses). One of the most important factors in the categorization of these groups is processing and analyses of tissues by experts using materials and methods that can

Correspondence: Sümeyye EKMEKÇí

Department of Pathology, Dokuz Eylül University, Faculty of Medicine,

IZMIR, TURKEY

E-mail: sumeyye.ekmekci@deu.edu.tr Phone: +90 5055360018 
only be found in a modern pathology laboratory. Although minimum material and effort are used in the first category of products, the use of extensive material and expert effort are required to achieve the products in the third category. The third category of products provides valuable diagnostic and often prognostic information through the use of technology by the experts in a pathology department. Thus, an added is created by processing the tissue obtained from patients, which in turn provides the critical information for disease diagnosis and management.

The information obtained from the analysis of the tissues should be delivered to the patients and the treating physicians as soon as possible. Many countries have enacted laws that regulate how this information should be transferred as well as who has legal access to this information. For example, Health Insurance Portability and Accountability Act (HIPAA) which has been in effect since 1996 in the US regulates the privacy and the secure use of individual's health information. HIPAA aims to avoid and eliminate conflicts that may occur during the use, distribution and storage of the healthcare information that belong to patients. Such information, often referred to as protected health information (PHI) includes any information about health status, provision of health care, or payment for health care that can be linked to a specific individual. This is interpreted rather broadly and includes any part of a patient's medical record or payment history and must be kept confidential. Every information that can be determined to belong to a private person under reasonable conditions must be considered within the scope of this law and should be protected. Since the regulations are only concerned with PHI, the actual tissues and material and their possession is beyond the scope of HIPAA.

\section{DEFINING THE PROBLEM}

A series of questions emerge during the processing and use of tissues mentioned above with the workflow of a pathology department. The most critical questions within the scope of our article are:

1) Who owns the tissues obtained from patients and are subsequently embedded in paraffin blocks and processed using special techniques in pathology departments?

2) Who owns the information and PHI related to these tissues?

3) How should the information obtained from these tissues be shared with the patient, physicians and other legal entities for the purpose of healthcare? What are the rights of the hospital, pathology department and patients regarding this information?
4) Who should authorize the use of pathology material for health education and research purposes?

While these questions may appear simple, they pose serious dilemmas and the answers can lead to significant social and legal problems in many countries today. Naturally, the answers to these questions have serious implications for all kinds of tissues or information obtained from patients in addition to those submitted to pathology departments. However, due to the unique nature of the tissues submitted to pathology department and these questions should be answered specifically for pathology and not be generalized. For practical reasons, certain issues relating to pathology material should be examined separately while answering these questions. First and foremost, pathology materials should be classified according to certain categories such as the following: 1- Tissues that are minimally processed and require mostly for archiving and storage expenses (fresh or frozen, tissues), 2- tissues that are made suitable for long-term archiving using special procedures and material (paraffin blocks or polymer-embedded tissue), 3- tissues that are processed for diagnostic purposes by using special stains and molecular methods (immunohistochemistry, in situ hybridization, histochemical stains, etc.).

The problems relating to the use of tissue for purposes of 1) Patient Care 2) Healthcare Education and 3) Research are concepts that should also be discussed and evaluated separately. Questions relating to all three areas have critical importance in improving the healthcare in our country.

\section{EXAMPLES FROM THE WORLD AND EXPERIENCES}

The ethical and legal problems created by the four questions mentioned above have been the subject of many books and articles. Most of these resources are relate to the duration of storage of pathology material as tissue blocks and microscopic slides. However, many countries have developed or are in the process of developing regulations that deal with the above questions. It appears that two diametrically opposite points of view exists, one suggests that the pathology materials are not different than organs and tissues as a whole, whereas the other suggests that they are a part of the clinical records (2).

\section{Property Rights of the Tissues}

The property rights of tissues obtained from patients and analyzed in pathology departments are not clear in many countries. For example, in Cornelio v. Stamford Hospital, the Connecticut Supreme Court decided that the pathology material that consisted of glass slides was the property of the hospital (3). The court also stated that the Papanicolau (Pap) 
smear slides were part of the medical records of the hospital and found against the plaintiff (3). The Supreme Court's majority decision stated that the pathology slides were a part of patient's permanent records and the hospital is charged with the preservation of all original material including the material that cannot be duplicated. The Supreme Court also reaffirmed the responsibility of the pathology departments in the storage and safe keeping of pathology material within the period stated by the existing rules and regulations. The decision of the Connecticut Supreme Court effectively separates the patient from the control and property rights of tissues removed from that patient. Connecticut State legislation also identifies the material that cannot be duplicated as the permanent property of the hospital and that patients cannot claim property rights to such material. (4). In Moore v. UC Regents, the California Supreme Court decided that the organs removed from patients surgically for treatment purposes no longer belong to the patient (5). The California Supreme Court decision has set a very significant precedence for all US State Legislation and courts.

The United Kingdom, a constitutional monarchy, has enacted the Human Tissue Act (HTA) (applicable in England, Wales and Northern Ireland) which regulates the procurement, use and disposal of tissues obtained from live or deceased patients which commenting on any issue relating to property rights (6). The HTA had been revised in 2004 following a major scandal. Between 1988 and 1995, more than 2.000 organs that were removed during autopsy (850 of these from newborns) were kept without authorization at the Liverpool Alder Hey Children's Hospital. The revelation of unauthorized use of so many tissues prompted a revision of the original HTA that had been in effect since 1961. The Human Tissue Authority created by the revised HTA was charged with resolving the conflicts relating to the property rights of tissues as well as other issues relating to the use of human tissue (6). Scotland is not included within the scope of this law and this country has enacted a similar law independently. The HTA covers all tissues that contain human cells except for hair, nail gamete, embryos and cell cultures. According to this law, analysis of human DNA from tissue without approval is a crime, but the use of existing DNA extracts are not subject to authorization or approval. These changes increased the anxieties of the medical researchers and educators due to added restraints on the use of human tissue.

In Australia, the Supreme Court has also accepted that once removed out of the body for treatment or diagnostic purposes, the tissues are no longer considered the property of individual and the property rights remained with the medical institution (7).

\section{Possession of Patient Related Information}

To the extent of our investigations, the property right of tissues obtained from patient are considered separately from the information obtained from their analyses and patient information in most countries. This fact implies that the patients have the ultimate authority to allow or request the analysis of their pathology material. In all countries where we found sufficient information, the patients have unfettered rights to access their medical records as well as information from pathological analysis. In addition, patients have the right to request review of their material by other pathologists or experts, although rules and regulations on this issue are quite variable (2). Furthermore, all pathology laboratories have the legal responsibility to provide the pathology information when requested by the patient or his/her legal guardian (2). This fact does not mean that the pathology laboratories need to relinquish the property rights to the material, but to the information. In the State of New York, medical institutions are required to provide copies of all radiographic studies, medical and laboratory records to patients or their legal representatives. (8). This rule does not necessitate the hospital to relinquish the original pathology material. However, on the contrary, the State of Connecticut legislation require that the medical institutions provide the original blocks and slides when the copies are deemed not to be adequate. The State of Connecticut laws also allow the laboratories to charge a reasonable fee to cover the cost of duplicating the material or records (4). The State law also requires that the person who receives the pathology material be responsible for its preservation and safe return. The hospitals or the medical institutions are not held liable in case the original material is damaged or lost (4).

As the principal legislation that governs the use of patient information or PHI, HIPAA does not contain any stipulation regarding the property rights of the tissues removed from the patient (2). HIPAA ensures the confidentiality and security of the health information of the individual that can in any way of form be used to reveal the patient's identity. The HIPAA regulates who can access this information, how they can be used and when this information can be shared. All electronic and non-electronic information that can easily identify the patient's identity are within the scope of this law. Legislators in European countries and Australia have also adopted many provisions of the HIPAA.

In summary, the common practice identified in all references reviewed during this study hands over the control 
of the information obtained from the pathology material to the patients and protects the patients' right to choose their physician and treatment. We believe that the property rights of the tissue should be considered separately from the property rights of the information obtained from the tissue in legislative initiatives in our country as well.

\section{The Use of Information Obtained from the Tissues for Healthcare Purposes}

The information obtained from the patient's tissues is often accompanied with other clinical and demographic information. The use of tissues obtained from patients during invasive procedures is not subject to further or separate consent for diagnostic procedures. Laws in effect in both European countries and the HIPAA in the U.S. stipulate that the use of human tissues for patient care purposes do not require any additional consent. The same legislations also require that the pathology material and the obtained information be shared with every authorized staff for healthcare purposes subject to the patient's permission. According to the guidelines established by the U.S. Ministry of Health under the scope of the HIPAA, protected health information must be secured and can only be given to the patient, to legal representatives or guardians or to third party payers legally authorized to utilize this information with limited scope (9). HIPAA provides detailed instructions on the use and share of PHI in regular as well as exceptional circumstances (1). HIPAA and its amendments explicitly identifies the necessity of obtaining consent for access to these information by others than the healthcare personnel directly responsible for the patient's diagnosis and treatment. HIPAA also includes rules that are also applicable in exceptional circumstances during medical care.

\section{The Use of Pathology Material for the Purpose of Health Education and Research}

Hospitals and pathology departments carry the responsibility of preserving and disposing of pathology material according to legislative requirements. During this storage period, pathology materials play a critical role as material for medical education and research. Furthermore, some pathology material is too valuable to discard and is kept within pathology departments for much longer periods to be used in education and research. Countless discoveries and innovations have been made possible with the use of pathology material in recent decades. Pathology material also plays a critical role in the training of medical students and healthcare staff. Therefore, the pathology departments are also charged with organizing the tissues obtained for clinical purposes for subsequent use in medical education and research. Without the use of these material it becomes virtually impossible to conduct any translational research in any pathology department. Some countries have laws that regulate the usage of pathology material for the purposes of training and research. HTA enacted in the United Kingdom includes stipulations that regulate such issues. The revised HTA of 2004 has replaced the guidebook containing ethical principles and procedures published by the Medical Research Council in the same country. The use of the tissues for research in the U.S.A. is regulated partly by the HIPAA and partly by the local and Supreme Court decisions that set the precedence regarding these issues. The case of Moore v. UC Regents and the decision of the Supreme Court in this case constitutes one of the most important precedence in matters of tissue property rights. The above mentioned case involved the use of an organ taken from the plaintiff for research purposes and producing cell cultures from these tissues with subsequent financial gain in the form of a patent and shares. The California Supreme Court rejected the patient's property rights claim on the cell culture produced from his tissue and the associated patents arising from this discovery. The Supreme Court stated the lack of regulations and experiences regulating the property rights of human tissue and the uncertainty on how tissues should be disposed. In addition, the court also stated that the product formed by processing the tissue no longer carried the original characteristics and therefore should be considered different and a product of human creativity.

Sections of the HIPAA law regulate the usage of patient information for research. In accordance with these rules, institutions should require the completion of consent forms aiming to keep health information confidential and containing comprehensive information related to the specific research project. Consent forms must comply with the legal requirements, clearly identify how and by whom the information will be used and should be signed by the patient. Some studies have reported that the cost and quality of medical research have been negatively influenced by the bureaucratic procedures required by HIPAA. For example, in a study by Michigan University, follow up surveys conducted after a heart attack showed a decrease in the participation rate from $96 \%$ to $34 \%$ due to the application of the HIPAA confidentiality rule (10). The investigators conducting this study accepted the importance of the confidentiality, but stated that these rules should not make medical research and innovation difficult. The College of American Pathologists (CAP) made a number of suggestions about the use of human tissue in research, 
education and quality control. These recommendations are intended to balance the privacy requirements with the necessity of conducting research in everyday life.

While pathology material from patient can be used for healthcare purposes without the patient's consent, the commercial use of these tissues pose an entirely different challenge. The American Medical Association (AMA) has adopted the following ethical principles in the document published under the name of "commercial use of human tissue": (1) Informed consent must be obtained from patients for the use of organs or tissues in clinical research, (2) Potential commercial applications must be disclosed to the patient before a profit is realized on products developed from biological materials, (3) Human tissue and its products may not be used for commercial purposes without the informed consent of the patient who provided the original cellular material, (4) Profits from the commercial use of human tissue and its products may be shared with patients, in accordance with lawful contractual agreements, (5) The diagnostic and therapeutic alternatives offered to patients by their physicians should conform to standards of good medical practice and should not be influenced in any way by the commercial potential of the patient's tissue (12).

In the Moore v. UC Regents case, the tissues obtained from the patient generated a significant commercial profit. In this case, the high court decided that the patient does not have a right to profit from the tissue's commercial use. The Supreme Court clearly stated that cells obtained for any purpose in medical institutions should not be accepted as the property of the patient. This legal case is the only and the most critical precedence regarding the profits that can be obtained following research on patients' tissues.

Many organizations and experts recommend certain principles to avoid such conflicts that may occur during or following research with pathology material. For example, Mohapatra et al. made a series of suggestions in order to prevent pathologists from facing such problems. They state that the pathologists may wish to get assurances of the following: 1) Patients have been informed of the risks and benefits, (2) Patients have given consent to use of the sample for research (3) Patients have been informed of any possible commercial interests in this research (4) Tissues already stored by the laboratory are made anonymous or granted institutional review board (IRB) waivers (2).

Many studies contend that it should be possible to perform research on pathology material leftover from diagnostic or therapeutic procedures with only institutional ethical and scientific approval and without a special consent from the patient. In addition, all consent forms used for the surgery and invasive initiatives should specify whether the tissues obtained from the patient will be used for research purposes. The patients should be informed and should be told that they have the right to reject if they want (13). If obtaining consent is not practical or possible, the consent of an IRB committee should be enough (13).

\section{REQUIREMENTS REGARDING THE POSSESSION AND USE OF PATHOLOGY MATERIAL IN OUR COUNTRY}

Undoubtedly as in all other countries, there is a dire need for legislation that regulates the possession and use of pathology material in our country. The purpose of these laws should be the delivery of healthcare services in an uninterrupted manner and in accordance with modern standards, while providing the most fertile environment for sensible research and medical education that can set an admirable precedence. It is critically important to resolve the problems that may emerge from the uncertainties in legislation that regulates property rights of pathology material in addition to creating the most conducive environment for scientific progress and discovery. The purpose of the new laws should be to determine the property rights, conditions of use, storage and appropriate disposal of human organs and tissues and specifically pathology material (13). Future laws should balance patient rights with the rights and welfare of the society and promote public health, medical education and scientific research.

In summary, the basic principles that should be adopted in future legislation can be summarized as follows:

1. Pathology material obtained from patients and subsequently created paraffin embedded tissues and glass slides should be considered to be the property of the hospital or the governing healthcare organization.

2. The information that relates to the aforementioned tissues and products created from these tissue should be the property of the patient, legal representative or the legal guardian of the patient.

a. The pathology department should be responsible for preserving the confidentiality of information belonging to these patients or related diagnostic and prognostic information obtained from these tissues.

b. The use of this information should be dependent on the consent of the patient except for circumstances where such use is related to direct patient care. 
c. In cases when an informed consent cannot be obtained, the use of these tissues for research purposes should be dependent on IRB approval.

3. The information that has been created or that can be obtained from these tissues should be shared with any healthcare personnel who is directly responsible for the care of that patient without the necessity of obtaining informed consent.

a. The information that will be used for the care of the patient should only be given to the persons responsible for the care of the patient.

b. Healthcare personnel who are not responsible for the patient's care should obtain an informed consent from the patient or the patient's legal representative in order to access PHI.

c. Sharing of patient information for any other purpose should be dependent on the informed consent of the patient or the legal representative.

4. The authority to use the pathology material for education or research purposes should be given to the healthcare institution, which should be executed by the pathology departments. The decisions on the use of pathology material for education or research purposes should be subject to IRB approval.

a. IRBs should only require a signed informed consent when this is practically possible or for prospective research trials.

b. The general informed consent obtained from the patient before surgery or invasive procedures should be sufficient for the use of this material for educational and research purposes after IRB approval.

c. The requirements for informed consent and the rules and regulations of IRBs should be based on national standards or legislation. The principles and procedures followed by IRBs should also be determined within the national context. d. The use of pathology material for the purpose of education and research should not depend on the permission of any physician or staff who was responsible for that patient's care.

e. The use of pathology material for commercial purposes should be under the responsibility of the hospital administration or its governing organization. The hospitals and their governing organizations should also regulate the rules of sharing profits that may be gained through commercialization of the research products.

\section{REFERENCES}

1. U.S. Department of Health \& Human Services. Available from: www.hhs.gov/ocr/privacy

2. Mohapatra S, Kalogjera L: Who owns these slides? Overwiew of legal issues facing pathologists and laboratories when saving and sending out tissues, slides, and tissue blocks. Pathology Case Reviews 2003, 8:90-97

3. Cornelio V. Stamford Hospital, 246 Conn 45,49 717 A.2d 140 (1998). Docked number: 158.26

4. Conn General Statutes Annotated 19a-490b

5. Moore v. Regents of the University of California 51,3d 120. Docked number: S006987

6. United Kingdom, Human Tissue Act, 2004

7. Australia Coroners and Human Tissue Acts (Amendment) Act 2006. Available from: http://www.health.vic.gov.au/humantissue/ htact

8. N Y Public Health Law 17

9. U.S Government Printing Office: Federal Law Number: 45 CFR Part 160 subparts C, D and E. Available from: http://www.gpo. gov/fdsys/pkg/CFR-2007-title45-vol1/content-detail.html

10. Armstrong D, Kline-Rogers E, Jani S, Goldman E, Fang J, Mukherjee D, Nallamothu B, Eagle K: Potential impact of the HIPAA privacy rule on data collection in a registry of patients with acute coronary syndrome. Arch Intern Med 2005, 165: $1125-1119$

11. College of American Pathologists Policy on Uses of Human Tissue in Research, Education, and Quality Control. Adopted August 1996; reaffirmed August 2000.

12. AMA E-2.08 commercial use of Human Tissue. Available from: http://www.ama-assn.org

13. Samanta A, Samanta J, Price D: Who owns my body - thee or me? The human tissue story continues. Clin Med 2004, 4:327-331 